Gut and Liver, Vol. 10, No. 4, July 2016, pp. 617-623

\title{
Low-Dose Pegylated Interferon $\alpha-2 b$ Plus Ribavirin for Elderly and/or Cirrhotic Patients with Genotype 2 Hepatitis C Virus
}

Hideyuki Tamai ${ }^{1}$, Naoki Shingaki ${ }^{1}$, Yoshiyuki Mori ${ }^{1}$, Kosaku Moribata $^{1}$, Akira Kawashima $^{2}$, Yoshimasa Maeda ${ }^{1}$, Toru Niwa ${ }^{1}$, Hisanobu Deguchi ${ }^{1}$, Izumi Inoue ${ }^{1}$, Takao Maekita ${ }^{1}$, Mikitaka Iguchi ${ }^{1}$, Jun Kato ${ }^{1}$, and Masao Ichinose ${ }^{1}$

${ }^{1}$ Second Department of Internal Medicine, Wakayama Medical University, and ${ }^{2}$ Department of Internal Medicine, Naga Municipal Hospital, Wakayama, Japan

Background/Aims: This study aimed to predict sustained viral response (SVR) to low-dose pegylated interferon (PEGIFN) plus ribavirin of elderly and/or cirrhotic patients with genotype 2 hepatitis $C$ virus (HCV) using viral response within 2 weeks. Methods: Low-dose PEG-IFN- $\alpha-2 b$ plus ribavirin was administered to 50 elderly and/or cirrhotic patients with genotype $2 \mathrm{HCV}$ for 24 weeks. The dynamics of HCV RNA and HCV core antigen levels within 2 weeks were measured. Results: The patients' median age was 66 years. There were 21 male and 29 female patients. The median baseline HCV RNA level was $5.7 \log \mathrm{IU} / \mathrm{mL}$. Rapid viral response was achieved in 17 patients (34\%), SVR in 28 (56\%), and two (4\%) discontinued treatment. Univariate analysis of factors contributing to SVR showed significant differences for sex, baseline virus level, and response within 4 weeks. When 40 $\mathrm{fmol} / \mathrm{L}$ was set as the cutoff value for the core antigen level at 1 week, the sensitivity, specificity, positive predictive value, negative predictive value, and accuracy for predicting SVR were $93 \%, 75 \%, 84 \%, 88 \%$, and $85 \%$, respectively. Conclusions: Low-dose PEG-IFN plus ribavirin was a safe and costeffective treatment for elderly and/or cirrhotic patients with genotype $2 \mathrm{HCV}$, and the viral response within 2 weeks was a useful predictor of SVR. (Gut Liver 2016;10:617-623)

Key Words: Liver cirrhosis; Elderly; Hepacivirus; Pegylated interferon; Ribavirin

\section{INTRODUCTION}

As elderly and/or cirrhotic patients with chronic hepatitis C are at high risk of developing hepatocellular carcinoma, ${ }^{1}$ antiviral therapy should be started as soon as possible. ${ }^{2}$ Furthermore, cirrhotic patients who achieved a sustained viral response (SVR) reportedly had a marked reduction in liver-related mortality. ${ }^{3}$ However, thus far, the standard care for patients infected with hepatitis C virus (HCV) has been based on pegylated interferon (PEG-IFN) plus ribavirin therapy, and the effects and tolerability of this regimen in elderly and/or cirrhotic patients are limited., However, when doses of PEG-IFN and ribavirin are decreased, such treatment becomes tolerable even for patients generally considered ineligible, such as elderly and/or cirrhotic patients. ${ }^{6-9}$ In fact, Japanese guidelines for the management of HCV recommend a decreased dose of PEG-IFN and ribavirin for treatment of cirrhotic patients. ${ }^{2}$

Recently, some direct antiviral agents (DAAs) effective against HCV have been developed, and the first interferon-free therapy using asunaprevir and daclatasvir for patients with genotype $1 \mathrm{HCV}$, who are not responsive to, and are intolerant of and ineligible for, interferon-based therapy, has been approved for use under National Medical Insurance in Japan..$^{10}$ In addition, the safety and effectiveness of sofosbuvir plus ribavirin for patients with genotype $2 \mathrm{HCV}$ has been reported. ${ }^{11,12}$ In the near future, some types of interferon-free, DAA therapies will be available worldwide. However, problems with interferon-free therapy include the high drug $\operatorname{costs}^{13}$ and the induction of drug resistance after treatment failure. ${ }^{14}$ In many countries, these safe and effective interferon-free therapies might not be available for use because of economic constraints. However, as effects of PEG-IFN plus ribavirin for patients with genotype $2 \mathrm{HCV}$ are better than those for patients with genotype 1 , and there is no significant difference in SVR rate between the recommendedand reduced-dose regimens, ${ }^{15}$ this would remain a cost-effective treatment. Therefore, if low-dose PEG-IFN plus ribavirin is considered a tolerable treatment for generally ineligible patients,

Correspondence to: Hideyuki Tamai

Second Department of Internal Medicine, Wakayama Medical University, 811-1 Kimiidera, Wakayama 641-0012, Japan

Tel: +81-73-447-2300, Fax: +81-73-445-3616, E-mail: tamahide@wakayama-med.ac.jp

Received on April 23, 2015. Revised on June 16, 2015. Accepted on June 25, 2015. Published online November 27, 2015

pISSN 1976-2283 eISSN 2005-1212 http://dx.doi.org/10.5009/gnl15193

() This is an Open Access article distributed under the terms of the Creative Commons Attribution Non-Commercial License (http://creativecommons.org/licenses/by-nc/4.0) which permits unrestricted non-commercial use, distribution, and reproduction in any medium, provided the original work is properly cited. 
such as elderly and/or cirrhotic patients, accurate prediction of SVR for the reduced-dose regimen becomes more important for determining an optimal treatment strategy.

With PEG-IFN plus ribavirin therapy at the recommended dose for 24 weeks in patients with genotype $2 \mathrm{HCV}$, a rapid virological response (RVR), defined as serum HCV RNA negativity at 4 weeks, is known to be the most useful predictor of SVR; ${ }^{16}$ however, accurate prediction factors for the low-dose regimen have not been established. If an even earlier virological response can predict SVR as accurately as RVR (at 4 weeks), a trial administration of PEG-IFN plus ribavirin for 1 or 2 weeks would be a sensitive test for predicting SVR.

The aim of the present study was to determine factors predictive of SVR during low-dose PEG-IFN plus ribavirin therapy for elderly and/or cirrhotic patients with genotype $2 \mathrm{HCV}$, using viral response within 2 weeks of therapy initiation.

\section{MATERIALS AND METHODS}

\section{Patients}

This was a prospective cohort study of low-dose PEG-IFN$\alpha-2 b$ plus ribavirin therapy for patients with a genotype $2 \mathrm{HCV}$ infection. A total of 50 elderly and/or cirrhotic patients were enrolled from March 2008 to April 2014 in Wakayama Medical University Hospital and Naga Municipal Hospital. "Elderly" was defined as more than 65 years of age. Liver cirrhosis was diagnosed clinically by imaging studies using the morphologic signs of cirrhosis from portal hypertension, such as portosystemic shunt or hypersplenism. Exclusion criteria were (1) pregnant women, women who may have been pregnant, lactating women, men whose partners were pregnant, or men whose partners hoped to become pregnant; (2) patients who used Shosaikoto (a Kampo medicine); (3) intractable heart disease; (4) renal failure or renal dysfunction with creatinine clearance $<50 \mathrm{~mL} / \mathrm{min}$; (5) patients with uncontrollable psychoneurotic disorders; (6) hemoglobin (Hb) levels < $10 \mathrm{~g} / \mathrm{dL}$; (7) platelet count $<50,000 / \mathrm{mm}^{3}$; (8) white blood cell count $<1,500 / \mathrm{mm}^{3}$ (or granulocyte count $<1,000 / \mathrm{mm}^{3}$ ); and (9) hepatic failure or cancer. All study protocols were approved by the ethics committees of the participating hospitals. Informed consent was obtained from all patients for being included in the study.

\section{Treatment regimens}

Two-thirds of the recommended dose of PEG-IFN- $\alpha-2 b$ (PegIntron $^{\circledR}$; MSD, Tokyo, Japan) and a dose of ribavirin (Rebetol ${ }^{\circledR}$; MSD) reduced by $200 \mathrm{mg}$ from the recommended dose in Japan were used; $1.0 \mu \mathrm{g} / \mathrm{kg}$ PEG-IFN- $\alpha-2 b$ was administered subcutaneously once a week, and ribavirin was given orally for 24 weeks $(800 \mathrm{mg} /$ day for patients weighing greater than $80 \mathrm{~kg}$, $600 \mathrm{mg} /$ day for patients weighing between 80 and $60 \mathrm{~kg}$, and $400 \mathrm{mg} /$ day for patients weighing less than $60 \mathrm{~kg}$ ).

The PEG-IFN- $\alpha-2 b$ and ribavirin doses were reduced or discontinued based on the following criteria: (1) if the $\mathrm{Hb}$ fell below $10 \mathrm{~g} / \mathrm{dL}$, the ribavirin dose was reduced (to $400 \mathrm{mg} /$ day from $600 \mathrm{mg} /$ day, to $600 \mathrm{mg} /$ day from $800 \mathrm{mg} /$ day, or to 800 $\mathrm{mg} /$ day from 1,000 mg/day), and if the $\mathrm{Hb}$ fell below $8.5 \mathrm{~g} / \mathrm{dL}$, the ribavirin was discontinued; (2) if the granulocyte count fell below $750 / \mathrm{mm}^{3}$ or the platelet count fell below $70,000 / \mathrm{mm}^{3}$, the PEG-IFN dose was reduced to $0.75 \mu \mathrm{g} / \mathrm{kg}$; (3) if the granulocyte count fell below $500 / \mathrm{mm}^{3}$ or the platelet count fell below $30,000 / \mathrm{mm}^{3}$, the PEG-IFN was discontinued; and (4) PEG-IFN and ribavirin were discontinued if deemed necessary by the attending physician because of adverse events. The dose of PEGIFN or ribavirin was increased back to the starting dose if cytopenia improved. If there was no improvement in hematological parameters within 4 weeks, this therapy was discontinued. Although granulocyte colony-stimulating factor (G-CSF) could be used as supplementary treatment for granulocytopenia of less than $500 / \mathrm{mm}^{3}$, erythropoietin was not allowed for treatment of anemia because the Ministry of Health in Japan had not approved its use.

\section{Laboratory tests and ultrasounds}

For all patients, laboratory tests and ultrasounds were performed before therapy began. Fatty liver was defined as positive hepato-renal contrast on ultrasound B-mode imaging. The amount of HCV RNA was measured using quantitative reverse transcription polymerase chain reaction (RT-PCR) (COBAS TaqMan Version 1.0 PCR assay; Roche Diagnostics, Branchburg, NJ, USA). Determination of HCV genotype was performed as reported by Simmonds et al.: ${ }^{17}$ the amount of HCV RNA and HCV core antigen levels (Ortho Clinical Diagnostics, Tokyo, Japan) were measured simultaneously at three time points (day of therapy initiation, and at weeks 1 and 2). Serum ribavirin concentration was measured at week 2. During therapy, and up to 24 weeks after the end of therapy, quantitative HCV RNA and biochemical analyses, including blood counts, serum alanine aminotransferase, and aspartate aminotransferase, were performed every 4 weeks.

\section{Assessment of effectiveness}

During IFN therapy, RVR was defined as undetectable virus by quantitative RT-PCR at week 4 after therapy initiation. SVR was defined as follows: HCV RNA measured using the TaqMan PCR assay was negative at the end of therapy and remained negative for 24 weeks after the end of therapy. No response was defined as detectable HCV RNA at week 24 from treatment initiation or at the end of treatment. Relapse was defined as negative at the end of therapy but positive 24 weeks after the end of therapy. The virological response within 2 weeks after therapy initiation was assessed by virus level at each of the three time points indicated above. 


\section{Assessment of safety and tolerability}

Patients were assessed for safety and tolerability during treatment by their attending physicians, who monitored adverse events and laboratory parameters, such as blood cell counts, every week up to week 8 , and monthly thereafter. The incidence and reasons for therapy discontinuation due to adverse effects were analyzed. Adherence to PEG-IFN- $\alpha-2 a$ and ribavirin were also assessed separately.

\section{Statistical analysis}

Therapeutic effectiveness was evaluated using an intentionto-treat analysis. Predictive factors for SVR were analyzed using a per protocol analysis that excluded patients who had discontinued therapy due to adverse events. The Mann-Whitney U test was used to analyze continuous variables. Fisher exact test or the chi-square test was used to analyze categorical variables. Multivariate analysis was performed using a logistic regression model with the stepwise method. The criterion for selecting factors for multivariate analysis was $p<0.05$. Each optimal cutoff value for continuous variables of SVR-predicting factors was decided by the Youden index method on the basis of the receiver operating characteristics curve. The SVR-predictability of significant SVR-contributing factors was evaluated by measuring the area under the receiver operating characteristic curve (AUC). The sensitivity, specificity, positive predictive value (PPV), negative predictive value (NPV), and accuracy for SVR were calculated on week 1 , week 2 , and RVR. The p-values of less than 0.05 were considered statistically significant. IBM SPSS statistical software version 20.0J for Windows (IBM SPSS Inc., Tokyo, Japan) was used for data analyses.

\section{RESULTS}

\section{Patients' baseline characteristics}

Patients' baseline characteristics are summarized in Table 1. There were 20 nonelderly and cirrhotic patients (40\%), eight elderly and noncirrhotic patients (16\%), and 22 elderly and cirrhotic patients (44\%) in the present study.

\section{Safety and tolerability}

Two patients (4\%) discontinued the therapy due to adverse effects. Reasons for discontinuation were severe anemia in one patient, and hyperthyroidism in one patient. The mean \% adherences (mean \pm standard deviation) to PEG-IFN- $\alpha-2 b$ and ribavirin among the 50 enrolled patients were $90 \% \pm 15 \%$ and $83 \% \pm 19 \%$, respectively. Dose reduction or interruption of PEGIFN- $\alpha-2 b$ was required in 21 patients (42\%) because of adverse effects including neutropenia, thrombocytopenia, and infectious diseases such as acute pyelonephritis or pharyngitis. Regular administration of G-CSF was required in two patients. Dose reduction or interruption of ribavirin because of anemia was required in 28 patients (56\%). The drug dose reduction or interruption rates of nonelderly and cirrhotic patients, elderly and noncirrhotic patients, and elderly and cirrhotic patients were 65\% (13/20), 63\% (5/8), and 77\% (17/22), respectively. The drug dose reduction or interruption rates of female and male patients were 86\% (25/29) and 48\% (10/21), respectively, significantly higher in female than in male patients $(\mathrm{p}=0.005)$.

\section{Treatment response}

RVR was achieved in 34\% of patients (17/50). SVR was achieved in 56\% (28/50), relapse occurred in 24\% (12/50), and no response was seen in $16 \%$ of patients (8/64). RVR rates of nonelderly and cirrhotic patients, elderly and noncirrhotic patients, and elderly and cirrhotic patients were 30\% (6/20), 38\% (3/8), and 36\% (8/22), respectively.

Table 1. Baseline Patient Characteristics

\begin{tabular}{|c|c|}
\hline Characteristic & Value $(n=50)$ \\
\hline Age, yr & $66(39-78)$ \\
\hline$<65$ & $20(40)$ \\
\hline$\geq 65$ & $30(60)$ \\
\hline \multicolumn{2}{|l|}{ Sex } \\
\hline Male & $21(42)$ \\
\hline Female & $29(58)$ \\
\hline Body weight, kg & $56.9(35.4-92.3)$ \\
\hline BMI, $\mathrm{kg} / \mathrm{m}^{2}$ & $22.8(16.8-43.2)$ \\
\hline Prior interferon therapy & $12(24)$ \\
\hline History of HCC treatment & $9(18)$ \\
\hline Liver cirrhosis & $42(84)$ \\
\hline Diabetes & $11(22)$ \\
\hline Hypertension & $17(34)$ \\
\hline Fatty liver & $14(28)$ \\
\hline \multicolumn{2}{|l|}{ Genotype } \\
\hline $2 \mathrm{a}$ & $34(68)$ \\
\hline $2 \mathrm{~b}$ & $16(32)$ \\
\hline HCV RNA, $\log \mathrm{IU} / \mathrm{mL}$ & $5.7(4.0-6.8)$ \\
\hline $\mathrm{HCV}$ core $\mathrm{Ag}, \mathrm{fmol} / \mathrm{L}$ & $1,670(31-12,400)$ \\
\hline White blood cells, $/ \mathrm{mm}^{3}$ & $3,595(1,990-9,540)$ \\
\hline Hemoglobin, g/dL & $13.0(10.4-16.1)$ \\
\hline Platelets, $\times 10^{4} / \mathrm{mm}^{3}$ & $11.0(5.4-27.7)$ \\
\hline ALT, IU/L & $70(19-173)$ \\
\hline$\gamma-\mathrm{GT}, \mathrm{IU} / \mathrm{L}$ & $40(15-324)$ \\
\hline$\alpha$-Fetoprotein, ng/mL & $9.7(1.6-228.0)$ \\
\hline Type IV collagen $7 \mathrm{~S}, \mathrm{ng} / \mathrm{mL}$ & $7.2(2.9-13.3)$ \\
\hline Hyaluronic acid, ng/mL & 246.6 (24.9-938.0) \\
\hline
\end{tabular}

Data are presented as median (range) or number of patients (\%). BMI, body mass index; HCC, hepatocellular carcinoma; HCV, hepatitis C virus; Ag, antigen; ALT, alanine aminotransferase; $\gamma$-GT, $\gamma$ glutamyl transferase. 
Table 2. Comparison of Pretreatment Factors between Patients with and without Sustained Virological Response

\begin{tabular}{|c|c|c|c|}
\hline Factor & SVR $(n=28)$ & Non-SVR $(n=20)$ & $\mathrm{p}$-value \\
\hline Age, yr & 65 (12.3) & $68(12.5)$ & 0.489 \\
\hline$<65 / \geq 65$ & $12 / 16$ & $8 / 12$ & 0.843 \\
\hline Sex, male/female & $15 / 13$ & $5 / 15$ & 0.048 \\
\hline Body weight, kg & $59.2(16.3)$ & $52.9(11.7)$ & 0.181 \\
\hline BMI, $\mathrm{kg} / \mathrm{m}^{2}$ & $23.1(2.8)$ & $22.2(3.9)$ & 0.352 \\
\hline Prior interferon therapy & 6 & 6 & 0.499 \\
\hline History of HCC treatment & 5 & 3 & 1.000 \\
\hline Liver cirrhosis & 24 & 17 & 1.000 \\
\hline Diabetes & 7 & 2 & 0.271 \\
\hline Hypertension & 8 & 8 & 0.408 \\
\hline Fatty liver & 9 & 5 & 0.591 \\
\hline Genotype, 2a/2b & $22 / 6$ & $11 / 9$ & 0.082 \\
\hline HCV-RNA, log IU/mL & $5.2(0.7)$ & $6.1(0.7)$ & 0.001 \\
\hline $\mathrm{HCV}$ core $\mathrm{Ag}, \mathrm{fmol} / \mathrm{L}$ & $623(2,114.8)$ & $4,830(4,797.5)$ & $<0.001$ \\
\hline White blood cells, $/ \mathrm{mm}^{3}$ & $3,680(1,880)$ & $3,670(1,565)$ & 0.341 \\
\hline Hemoglobin, g/dL & $13.2(2.1)$ & $12.8(1.8)$ & 0.225 \\
\hline Platelets, $\times 10^{4} / \mathrm{mm}^{3}$ & $10.9(5.0)$ & $10.7(5.7)$ & 0.738 \\
\hline ALT, IU/L & $80(65.5)$ & $56(82.5)$ & 0.069 \\
\hline$\gamma$-GTP, IU/L & $38(43.0)$ & 45 (70.5) & 0.770 \\
\hline$\alpha$-Fetoprotein, $\mathrm{ng} / \mathrm{mL}$ & $14.4(18.7)$ & $8.1(18.2)$ & 0.117 \\
\hline Type IV collagen 7S, ng/mL & $6.9(2.7)$ & $7.8(4.4)$ & 0.278 \\
\hline Hyaluronic acid, ng/mL & $241.6(305.2)$ & $260(272.9)$ & 0.931 \\
\hline
\end{tabular}

Data are presented as median (interquartile range) or number of patients.

SVR, sustained virological response; BMI, body mass index; HCC, hepatocellular carcinoma; HCV, hepatitis C virus; Ag, antigen; ALT, alanine aminotransferase; $\gamma$-GTP, $\gamma$-glutamyl transferase.

Table 3. Independent Pretreatment Factors Contributing to Sustained Virological Response on Multivariate Analysis

\begin{tabular}{lrrl}
\hline \multicolumn{1}{c}{ Factor } & p-value & OR & \multicolumn{1}{c}{$95 \% \mathrm{CI}$} \\
\hline Female sex & 0.147 & 0.331 & $0.074-1.476$ \\
HCV RNA , <5.9 log IU/mL & $<0.001$ & 12.964 & $3.072-54.709$ \\
\hline
\end{tabular}

$\mathrm{OR}$, odds ratio; $\mathrm{CI}$, confidence interval; $\mathrm{HCV}$, hepatitis $\mathrm{C}$ virus.

SVR rates of nonelderly and cirrhotic patients, elderly and noncirrhotic patients, and elderly and cirrhotic patients were 60\% (12/20), 50\% (4/8), and 55\% (12/22), respectively.

\section{Contributing factors for SVR and prediction of SVR}

Of 50 enrolled patients, 48 completed the study (excluding two patients who discontinued therapy due to adverse effects); 28 achieved SVR and 20 were non-SVR patients. Comparison of pretreatment factors between these groups of patients is summarized in Table 2. The comparison of the SVR and non-SVR group for pretreatment factors revealed significant differences for sex and for baseline levels of HCV RNA and HCV core antigen. As levels of HCV RNA and HCV core antigen were same factors, level of HCV RNA and sex were used for multivariate analysis. Results of the multivariate analysis of significant pre-
Table 4. Comparison of On-Treatment Factors between Patients with and without Sustained Virological Response

\begin{tabular}{lccc}
\hline \multicolumn{1}{c}{ Factor } & $\begin{array}{c}\text { SVR } \\
(\mathrm{n}=28)\end{array}$ & $\begin{array}{c}\text { Non-SVR } \\
(\mathrm{n}=20)\end{array}$ & $\mathrm{p}$-value \\
\hline HCV RNA level, log IU/mL & & & \\
$\quad$ At week 1 & $3.1(2.2)$ & $4.7(1.3)$ & $<0.001$ \\
At week 2 & $1.2(2.7)$ & $3.8(2.0)$ & $<0.001$ \\
At week 4 & $0(1.2)$ & $2.6(3.0)$ & $<0.001$ \\
RVR & 16 & 1 & $<0.001$ \\
HCV core Ag level, fmol/L & & & \\
At week 1 & $0(0)$ & $225(917.5)$ & $<0.001$ \\
At week 2 & $0(0)$ & $0(301.0)$ & $<0.001$ \\
PEG-IFN adherence, \% & $100(13.3)$ & $100(25.0)$ & 0.821 \\
Ribavirin adherence, \% & $100(26.0)$ & $76.5(30.0)$ & 0.257 \\
Ribavirin at week 2, ng/mL & $2,203(962.3)$ & $1,225(1,232.8)$ & 0.875 \\
\hline
\end{tabular}

Data are presented as median (interquartile range) or number of patients. SVR, sustained virological response; HCV, hepatitis C virus; RVR, rapid virological response; Ag, antigen; PEG-IFN, pegylated interferon.

treatment factors contributing to SVR are shown in Table 3; the baseline HCV RNA level was the only independent factor. Comparison of on-treatment factors between SVR and non-SVR 
patients is summarized in Table 4. On univariate analysis of ontreatment factors contributing to SVR, significant differences were noted for virus level within 4 weeks and RVR. However, no significant differences were seen for drug adherence and serum ribavirin level at week 2 . The AUCs according to significant SVR-predicting factors are summarized in Table 5. For all significant factors, the highest AUC for HCV RNA level was at week 4 and the highest AUC for HCV core antigen level was at week 1.

The sensitivity, specificity, PPV, NPV, and accuracy for SVR according to significant predictive virological factors within 4 weeks of therapy initiation are summarized in Table 6 . The accuracy for SVR of HCV RNA level at week 4 was the highest.

Table 5. Area under the Receiver Operating Characteristic Curve according to Significant Predictive Factors for Sustained Virological Response

\begin{tabular}{lccc}
\hline \multicolumn{1}{c}{ Factor } & AUC & p-value & \multicolumn{1}{c}{$95 \%$ CI } \\
\hline Male sex & 0.643 & 0.094 & $0.484-0.801$ \\
HCV RNA level, log IU/mL & & & \\
$\quad$ Baseline & 0.783 & 0.001 & $0.644-0.922$ \\
At week 1 & 0.883 & $<0.001$ & $0.786-0.980$ \\
At week 2 & 0.913 & $<0.001$ & $0.832-0.995$ \\
At week 4 & 0.914 & $<0.001$ & $0.826-1.000$ \\
RVR & 0.761 & 0.002 & $0.624-0.897$ \\
HCV core Ag level, fmol/L & & & \\
Baseline & 0.800 & $<0.001$ & $0.667-0.933$ \\
At week 1 & 0.856 & $<0.001$ & $0.735-0.977$ \\
At week 2 & 0.700 & 0.019 & $0.540-0.860$ \\
\hline
\end{tabular}

AUC, area under the receiver operating characteristic curve; CI, confidence interval; HCV, hepatitis C virus; RVR, rapid virological response; $\mathrm{Ag}$, antigen.

\section{DISCUSSION}

This prospective cohort study demonstrated the safety, efficacy, and prediction of effects of low-dose PEG-IFN plus ribavirin for elderly and/or cirrhotic patients with genotype $2 \mathrm{HCV}$ infection, who are generally considered ineligible for interferon therapy; the discontinuation rate in the present study was low $(4 \%)$ as compared to that (14.5\%) in previous reports of interferon therapy for cirrhotic patients. ${ }^{5}$ In terms of safety, it could be concluded that the low-dose regimen for genotype $2 \mathrm{HCV}$ was well tolerated even by elderly and/or cirrhotic patients. However, it has been reported that elderly patients or patients with diabetes have a high risk of developing severe infection during interferon therapy. ${ }^{18}$ Additionally, in our previous study of low-dose PEG-IFN plus ribavirin for patients with genotype $1 \mathrm{HCV}$, not only severe infection but also bone fractures due to falls occurred as characteristic adverse events in elderly and/ or cirrhotic patients. ${ }^{8,9}$ In the present study of patients with genotype $2 \mathrm{HCV}$, these characteristic adverse events did not occur. The reasons might include the shorter treatment duration than that for genotype $1 \mathrm{HCV}$, and the fact that patients were cautioned and counseled regarding prevention of these severe adverse events throughout treatment. Even when on a low-dose regimen, patients should pay attention to the possibility of occurrence of severe adverse events.

The SVR rate in the present study was relatively low compared to previous reports. ${ }^{19,20}$ In a report of PEG-IFN plus ribavirin for patients with genotype $2 \mathrm{HCV}$ infection, the reduceddose regimen was as effective as the recommended dose regimen, and it was better tolerated. ${ }^{6}$ Manns et al. ${ }^{21}$ reported that there was no significant difference in the SVR rate between low-dose $(1.0 \mu \mathrm{g} / \mathrm{kg})$ and standard-dose $(1.5 \mu \mathrm{g} / \mathrm{kg})$ PEG-IFN$\alpha-2 b$ for patients with genotype $2 \mathrm{HCV}$. Inoue et al. ${ }^{22}$ reported that reducing both PEG-IFN and ribavirin doses had no impact on RVR and SVR in patients with genotype 2 HCV. Therefore, a one-third dose reduction (as in the report of Manns et al. ${ }^{21}$ ) may

Table 6. Predictive Values of Significant Factors Related to Sustained Virological Response

\begin{tabular}{|c|c|c|c|c|c|}
\hline Significant predictive factor & Sensitivity & Specificity & PPV & NPV & Accuracy \\
\hline \multicolumn{6}{|l|}{ HCV RNA level, $\log I U / m L$} \\
\hline Baseline, $<5.9$ & $82(23 / 28)$ & $75(15 / 20)$ & $82(23 / 28)$ & $75(15 / 20)$ & $79(38 / 48)$ \\
\hline At week $1,<4.4$ & $93(26 / 28)$ & $75(15 / 20)$ & $84(26 / 31)$ & $88(15 / 17)$ & $85(41 / 48)$ \\
\hline At week $2,<3.2$ & $93(26 / 28)$ & $80(16 / 20)$ & $87(26 / 30)$ & $89(16 / 18)$ & $88(42 / 48)$ \\
\hline At week $4,<1.6$ & $100(28 / 28)$ & $75(15 / 20)$ & $85(28 / 33)$ & $100(15 / 15)$ & $90(43 / 48)$ \\
\hline RVR & $57(16 / 28)$ & $95(19 / 20)$ & $94(16 / 17)$ & $61(19 / 31)$ & $73(35 / 48)$ \\
\hline \multicolumn{6}{|l|}{ HCV core Ag level, fmol/L } \\
\hline Baseline, $<3,365$ & $89(25 / 28)$ & $60(12 / 20)$ & $76(25 / 33)$ & $80(12 / 15)$ & $77(37 / 48)$ \\
\hline At week $1,<40$ & $93(26 / 28)$ & $75(15 / 20)$ & $84(26 / 31)$ & $88(15 / 17)$ & $85(41 / 48)$ \\
\hline At week $2,<20$ & $100(28 / 28)$ & $40(8 / 20)$ & $70(28 / 40)$ & $100(8 / 8)$ & $75(36 / 48)$ \\
\hline
\end{tabular}

Data are presented as percent (number).

PPV, positive predictive value; NPV, negative predictive value; HCV, hepatitis C virus; RVR, rapid virological response; Ag, antigen. 
not affect the SVR rate. However, subjects of these studies were not mainly elderly and/or cirrhotic patients. It has also been reported that older age, male sex, advanced fibrosis or cirrhosis, a high baseline virus load, and metabolic factors are the most important negative predictive factors related to SVR in patients with genotype $2 \mathrm{HCV}^{23}$ The SVR rate of our previous study using the standard-dose regimen was 73\%, and older age and high fibrosis marker levels were significant unfavorable factors for achieving SVR. ${ }^{24}$ Therefore, it is presumed that the SVR rate of PEG-IFN plus ribavirin therapy for elderly and/or cirrhotic patients will be lower compared to that for nonelderly and noncirrhotic patients. The reason for the low SVR rate in the present study could be attributed to patients' characteristics such as advanced age and/or cirrhosis.

With regard to the factors predictive of SVR in the present study, sex, virus level, and viral response were significant factors by univariate analysis. In the present study, the dose reduction rate of ribavirin was significantly higher in female than male patients. However, on multivariate analysis, sex was not an independent factor. The present study indicated that viral response within 2 weeks was more valuable even than RVR. The most valuable predictor for SVR in the present study was the HCV RNA level at week 4. However, the HCV core antigen assay is better than that for the HCV RNA level in terms of lower cost, convenience, and more rapid results. ${ }^{25}$ Therefore, the HCV core antigen level at week 1 is considered as the most costeffective predictor because there were no significant differences in predictive accuracies among these significant predictive viral factors.

There are some limitations to the present study, the first being the small number of patients. Although HCV core antigen level at week 1 after therapy initiation was the most cost-effective predictor of SVR among the significant predictive factors, the pvalues for these factors were similar. In addition, although the optimal cutoff value for the core antigen level at 1 week was set at $40 \mathrm{fmol} / \mathrm{L}$ in the present study, in our previous study using a standard-dose regimen for genotype 2, $100 \mathrm{fmol} / \mathrm{L}$ was the best cutoff value. ${ }^{24}$ The optimal cutoff value might change in a study of an increased number of patients; in order to validate the present results, large-scale prospective studies are necessary. Secondly, there was no control group in the present study. To provide definitive evidence that the low-dose regimen for elderly and/or cirrhotic patients is safe and effective compared to the standard-dose regimen, a randomized controlled trial is desirable, but is impractical. Thirdly, interleukin (IL)-28B single nucleotide polymorphism (SNP) was not evaluated in the present study. Although it has been reported that IL28B SNP was not an accurate predictor of outcome of standard-dose PEG-IFN plus ribavirin therapy for genotype $2,{ }^{26}$ whether it is an accurate predictor for the low-dose regimen has not been determined.

In conclusion, from the analysis of viral dynamics within 2 weeks of therapy initiation, it was demonstrated that the HCV core antigen level at 1 week is the most cost-effective predictor of SVR to low-dose PEG-IFN- $\alpha$-2b plus ribavirin therapy in elderly and/or cirrhotic patients infected with genotype $2 \mathrm{HCV}$. The HCV core antigen level at 1 week could substitute for RVR in predicting SVR; this would enable a trial administration for predicting outcome. If the high SVR rate was predicted by the viral response to a trial administration, use of the low-dose PEG-IFN plus ribavirin regimen could be considered a safe and cost-effective treatment option for elderly and cirrhotic patients infected with genotype $2 \mathrm{HCV}$.

\section{CONFLICTS OF INTEREST}

No potential conflict of interest relevant to this article was reported.

\section{REFERENCES}

1. Asahina Y, Tsuchiya K, Tamaki N, et al. Effect of aging on risk for hepatocellular carcinoma in chronic hepatitis $\mathrm{C}$ virus infection. Hepatology 2010;52:518-527.

2. Editors of the Drafting Committee for Hepatitis Management Guidelines: The Japan Society of Hepatology. Guidelines for the management of hepatitis C virus infection: first edition, May 2012, The Japan Society of Hepatology. Hepatol Res 2013;43:1-34.

3. Morgan TR, Ghany MG, Kim HY, et al. Outcome of sustained virological responders with histologically advanced chronic hepatitis $\mathrm{C}$. Hepatology 2010;52:833-844.

4. Huang CF, Yang JF, Dai CY, et al. Efficacy and safety of pegylated interferon combined with ribavirin for the treatment of older patients with chronic hepatitis C. J Infect Dis 2010;201:751-759.

5. Bota S, Sporea I, Sirli R, et al. Severe adverse events during antiviral therapy in hepatitis $\mathrm{C}$ virus cirrhotic patients: a systematic review. World J Hepatol 2013;5:120-126.

6. Meyer-Wyss B, Rich P, Egger H, et al. Comparison of two PEGinterferon alpha-2b doses (1.0 or 1.5 microg/kg) combined with ribavirin in interferon-naive patients with chronic hepatitis $\mathrm{C}$ and up to moderate fibrosis. J Viral Hepat 2006;13:457-465.

7. Roffi L, Colloredo G, Pioltelli P, et al. Pegylated interferon-alpha2b plus ribavirin: an efficacious and well-tolerated treatment regimen for patients with hepatitis $\mathrm{C}$ virus related histologically proven cirrhosis. Antivir Ther 2008;13:663-673.

8. Tamai H, Shingaki N, Shiraki T, et al. Prediction of sustained response to low-dose pegylated interferon alpha-2b plus ribavirin in patients with genotype $1 \mathrm{~b}$ and high hepatitis $\mathrm{C}$ virus level using viral reduction within 2 weeks after therapy initiation. Hepatol Res 2011;41:1137-1144.

9. Tamai H, Mori Y, Shingaki N, et al. Low-dose pegylated interferon-alpha2a plus ribavirin therapy for elderly and/or cirrhotic patients with HCV genotype-1b and high viral load. Antivir Ther 2014;19:107-115.

10. Kumada H, Suzuki Y, Ikeda K, et al. Daclatasvir plus asunaprevir 
for chronic HCV genotype 1b infection. Hepatology 2014;59:20832091.

11. Zeuzem S, Dusheiko GM, Salupere R, et al. Sofosbuvir and ribavirin in HCV genotypes 2 and 3. N Engl J Med 2014;370:19932001.

12. Omata M, Nishiguchi S, Ueno $\mathrm{Y}$, et al. Sofosbuvir plus ribavirin in Japanese patients with chronic genotype $2 \mathrm{HCV}$ infection: an open-label, phase 3 trial. J Viral Hepat 2014;21:762-768.

13. Steinbrook R, Redberg RF. The high price of the new hepatitis $C$ virus drugs. JAMA Intern Med 2014;174:1172.

14. Murakami E, Imamura M, Hayes CN, et al. Ultradeep sequencing study of chronic hepatitis $\mathrm{C}$ virus genotype 1 infection in patients treated with daclatasvir, peginterferon, and ribavirin. Antimicrob Agents Chemother 2014;58:2105-2112.

15. Abergel A, Hezode C, Leroy V, et al. Peginterferon alpha-2b plus ribavirin for treatment of chronic hepatitis $\mathrm{C}$ with severe fibrosis: a multicentre randomized controlled trial comparing two doses of peginterferon alpha-2b. J Viral Hepat 2006;13:811-820.

16. Fried MW, Hadziyannis SJ, Shiffman ML, Messinger D, Zeuzem S. Rapid virological response is the most important predictor of sustained virological response across genotypes in patients with chronic hepatitis C virus infection. J Hepatol 2011;55:69-75.

17. Simmonds P, Holmes EC, Cha TA, et al. Classification of hepatitis $\mathrm{C}$ virus into six major genotypes and a series of subtypes by phylogenetic analysis of the NS-5 region. J Gen Virol 1993;74(Pt 11): 2391-2399.

18. Roomer R, Hansen BE, Janssen HL, de Knegt RJ. Risk factors for infection during treatment with peginterferon alfa and ribavirin for chronic hepatitis C. Hepatology 2010;52:1225-1231.
19. Manns MP, McHutchison JG, Gordon SC, et al. Peginterferon alfa2b plus ribavirin compared with interferon alfa-2b plus ribavirin for initial treatment of chronic hepatitis C: a randomised trial. Lancet 2001;358:958-965.

20. Ghany MG, Strader DB, Thomas DL, Seeff LB; American Association for the Study of Liver Diseases. Diagnosis, management, and treatment of hepatitis C: an update. Hepatology 2009;49:13351374.

21. Manns M, Zeuzem S, Sood A, et al. Reduced dose and duration of peginterferon alfa- $2 \mathrm{~b}$ and weight-based ribavirin in patients with genotype 2 and 3 chronic hepatitis C. J Hepatol 2011;55:554-563.

22. Inoue $\mathrm{Y}$, Hiramatsu N, Oze T, et al. Factors affecting efficacy in patients with genotype 2 chronic hepatitis $\mathrm{C}$ treated by pegylated interferon alpha-2b and ribavirin: reducing drug doses has no impact on rapid and sustained virological responses. J Viral Hepat 2010;17:336-344.

23. Petta $S$, Craxi A. Optimal therapy in hepatitis $C$ virus genotypes 2 and 3 patients. Liver Int 2011;31 Suppl 1:36-44.

24. Wada Y, Tamai H, Uno A, et al. Prediction of efficacy to pegylated interferon-alpha-2b plus ribavirin in patients with genotype 2 hepatitis $\mathrm{C}$ virus using viral response within 2 weeks. Hepatol Res 2014;44:179-186.

25. Hayashi K, Hasuike S, Kusumoto K, et al. Usefulness of a new immuno-radiometric assay to detect hepatitis $\mathrm{C}$ core antigen in a community-based population. J Viral Hepat 2005;12:106-110.

26. Jeng WJ, Lin CY, Chen JY, Huang CW, Huang CH, Sheen IS. None of the six SNPs of IL28B could predict treatment responses in genotype 2 chronic HCV infected patients by propensity score matching analysis. PLoS One 2012;7:e48217. 